\title{
Trends in Indian Private Sector Bank Efficiency: Non-Stochastic Frontier DEA Window Analysis Approach
}

\author{
Ashish KUMAR ${ }^{1}$, Nakul ANAND ${ }^{2}$, Vikas BATRA ${ }^{3}$
}

Received: August 01, 2020 Revised: September 06, 2020 Accepted: September 11, 2020

\begin{abstract}
The study examines the efficiency of private sector banks in India with the help of Window DEA (Data Envelopment Analysis) for a period from 2005 to 2017 . With a window of three years, the period was divided into 11 windows. The study outcomes show that $59.9 \%$ of all private sector banks in India operate at more than 0.9 level of efficiency, and there are only three occasions when banks were operating at the efficiency value between 0.6 to 0.7 . Further, the consistency in the efficiency scores of the banks has also been analyzed using an efficiency mapping matrix, and the mean efficiency score of the bank in each window is studied. The score of standard deviation was interpreted accordingly for these banks. Banks that are showing the highest efficiency scores also have a higher variance of efficiency scores. There was no bank identified in the matrix that promises high-efficiency ratings with low variability. The study concludes that the analysis of the efficiency mapping matrix indicates that, as a DMU escalates in the efficiency scores, the standard deviation reflecting the risk in overall efficiency scores also tends to rise. The findings complement the concept of higher risk to higher return or greater efficiency.
\end{abstract}

Keywords: Bank Efficiency, DEA, Window Analysis, Indian Banking Sector

JEL Classification Code: C67, D24, G21, O33

\section{Introduction}

The efficiency of the banking system is quintessential for the growth of a country as only an efficient bank can promise healthy and sustainable growth for the country's financial sector. A profitable bank is also perceived to be less risky and is more promising for the growth of the financial sector of the economy. Therefore, stakeholders and regulators need to evaluate from time to time the health of the bank system

${ }^{1}$ First Author. Assistant Professor, University School of Management Studies, Guru Gobind Singh Indraprastha University, New Delhi, India [Postal Address: Sector 16 C, Dwarka, Delhi, 110078, India] Email: ashish_prl@yahoo.com

${ }^{2}$ Corresponding Author. Research Scholar, University School of Management Studies, Guru Gobind Singh Indraprastha University, New Delhi, India [Postal Address: Sector 16 C, Dwarka, Delhi, 110078, India] Email: write2nakul@gmail.com

${ }^{3}$ Assistant Professor, Department of Economics, Indra Gandhi University, Rewari, India. Email: vikasbatra7@gmail.com

(c) Copyright: The Author(s)

This is an Open Access article distributed under the terms of the Creative Commons Attribution Non-Commercial License (https://creativecommons.org/licenses/by-nc/4.0/) which permits unrestricted non-commercial use, distribution, and reproduction in any medium, provided the original work is properly cited. to eliminate anomalies and support the country's economic growth. The Indian banking system has a mixed blend of private, public, and foreign banks, and the contribution of any category of banks to the overall growth of the Indian economy and stability of its financial system cannot be ignored. The government has rightly understood that without the support of private banking players, the Indian banking system cannot be improved. The reports of Reserve Bank of India (RBI) also indicate that lending by the private sector in India has soared substantially in the past couple of years in different sectors. The skewed distribution of the number of branches of private sector banks in rural and urban areas has also been altered significantly. Many empirical studies carried out in the past have shown that banks in the private sector are more efficient and better administered in comparison to their peers in the public sector. Private sector banks have also helped in raising the benchmark level of their public sector peers (Das \& Kumbhakar, 2016; Hassan, 2019; A. Kumar, 2011). Given the importance of private sector banks in promising economies like India, it is crucial to examine the efficiency, productivity, and performance of these banks from time to time. Studies of (Arora, 2017; A. Mukherjee, Nath, \& Pal, 2003; Singh \& Thaker, 2016) 
validate that globally there is an ever-increasing contribution of private sector banks in the financial sector especially in the banking sector of a developing country.

In recent years of research and development, there is a growing inclination amongst the researchers towards the area of efficiency and performance mapping of the banking sector, to which India is no exception. Researchers have long studied the cause of poor efficiency of the Indian banking system. Some of the famous studies (Lovell, Bhattacharyya, Lovell, \& Sahay, 1997) have examined various issues related to it, and the results of these studies have shown a gap in analyzing the efficiency of the banks. Since then, there has been ample empirical evidence (Anand \& Kumar, 2020; Mutiga, Mushongi, \& Kangéthe, 2019; Sensarma, 2008; Singh \& Thaker, 2016), which focus on building an efficiency frontier and a mapping system in the banking sector, but there are only a few microeconomic studies that attempt to measure the efficiency using window analysis and, fewer have focused their attention on developing nations. Besides this, most of the earlier studies have been carried out in the context of public sector banks only, and separate studies for private sector banks are very few in number to establish a valid conclusion. Our study intends to bridge these gaps. Further, banks' efficiency mapping studies could potentially help policymakers, researchers, industry leaders, and many others affected by this sector.

Against this backdrop out study aims to measure trends in Indian private banks' efficiency scores from 2005 to 2017 using window data envelopment analysis. Such rigorous analysis of private-sector Indian banks with a scope of covering both pre-recession and post-recession periods has not been carried out earlier in the Indian banking sector, which is also the novelty of our study.

Further, this study contrasts and compares the deviation in efficiency scores for the period of 2005 to 2017 and formulates an efficiency mapping matrix. The results of the study are of high relevance to the respective bank management, policymakers, researchers, and academicians in understanding the operating and intermediate efficiency.

\subsection{About Indian Banking}

Indian banking is led by RBI, the apex institution that governs the operations of all banks in India. Indian banks can further be classified under the ownership structure as the private sector, public sector, and other regional rural banks. The industry has experienced a wide variety of reforms and changes since its inception in the 18th century. It is only recently that this industry has recognized the importance of private ownership and foreign capitalization.

Despite the reforms in the Indian financial sector, there are still many challenges in the banking system. Some of the significant difficulties in current banking scenario are the technological gap observed across various ownership in the banks, increasing non-performing assets, corporate governance issues in private sector banks lack autonomy for public sector banks, heightened competition within the sector especially from foreign banks and lastly, meager services provided by several public sector banks.

\section{Literature Review}

In the banking sector, there had been many incidences that conclude comprehensive research, focusing on assessing the bank's resource utilization capabilities. The most prominent one and popular way of quantifying performance is the 'frontier efficiency approach.' In this approach, the frontier is formed by the locus of efficiency scores of most efficient banks. Further, studies of (Akhigbe et al., 2017; Doan et al., 2018; Forcadell et al., 2019; Saad \& El-Moussawi, 2009; Tecles \& Tabak, 2010) had used various applications of the traditional frontier analysis, namely 'stochastic frontier analysis,' 'thick frontier analysis,' 'data envelopment analysis,' etc.

A compilation of a study on 'Literature of efficiency of the financial institution' (Berger \& Mester, 1997)showed that less than $5 \%$ researches had studied the efficiency of the bank in a developing nation and that majority of the research are directed to developed countries such as the US and the European nations. Some of the studies, which have helped understand the banking system of developing nations include (Asmild et al., 2018; Baten et al., 2015), which are some of the prominent studies from Bangladesh, (Barros \& Wanke, 2014; Tecles \& Tabak, 2010; Wanke \& Barros, 2014) are studies from Brazil, (Avkiran, 2015; Ji et al., 2019; Ma et al., 2019; Zhou et al., 2008) are studies from China, (Anand \& Kumar, 2020; Bawa et al. , 2019; Behera, 2019; George, 2016; Kumar \& Dhingra, 2016b; Kumar, 2013; Padake \& Soni, 2015) are some prevalent studies in Indian banking sector, (Abbas et al., 2019; Ahmad, 2011; Akhtar, \& Nishat, 2002; Tahir et al., 2016) are some studies in Pakistan, (Miencha \& Selvam, 2013) is study from Kenya, (Seelanatha, 2010; Wijesiri et al., 2015) are studies from Sri Lanka, (Mahathanaseth \& Tauer, 2014; Sufian et al., 2010) are some studies from Thailand, (Eyceyurt et al., 2017; Gunes \& Yilmaz, 2016) are some studies from Turkey, and many other similar studies (Banna et al., 2017; Le, 2020; Nguyen, 2020)from different countries. These studies have highlighted the inefficiencies and their causes for the banking sector of developing nations.

Researchers have devised a wide variety of methods for efficiency measurement. Initial Efficiency Measurement Approach was narrowed to ratio testing to assess the efficiency of banks (Almumani, 2013; Gaganis et al., 2009; Gemar et al., 2019; Gupta et al., 2008; Martín \& Román, 2001; Mukherjee et al., 2002; Padake \& Soni, 2015; Pham Thien et al., 2015). Despite multiple traces for the use of ratio analysis in the literature, the technique suffers a significant 
limitation of subjective yardsticks and standards that may deceive the forecaster (Yeh, 1996).

Apart from ratio computations, an alternative approach of assessing efficiency is centered on the application of the quantitative technique and linear programming models. Data Envelopment Analysis (DEA) propounded by (Charnes \& Cooper, 1984) is a linear programming technique and is more prevalent than the conventional ratio analysis. It is a tool for measuring effectiveness based on a non-parametric approach on a set of given decision-making units (DMUs), which are homogenous in nature by linking the ratio of several outputs to relevant inputs (Charnes \& Cooper, 1984). The prominent studies, which have used DEA in this area are contributed by(Asmild et al., 2013; Avkiran, 1999; Banya \& Biekpe, 2018; Barros et al., 2012; Das et al., 2004; A. Kumar, 2011; A. Kumar \& Dhingra, 2016a; Kumar \& Gulati, 2009; Nandi, 2013; Nausshad et al., 2020; Paradi et al., 2018; Saha \& Ravisankar, 2000; Sathye, 2005; Sathye \& Khankhoje, 2009; Wanke et al., 2016).

Although DEA is an extensively used and wellacknowledged technique for measuring efficiency in any given set of decision-making units, this approach is often referred to as the black-box approach for studying effectiveness, which faces some severe limitations. One of the primary limitations of the traditional black-box approach of studying DEA is that it neglects the internal linkages between variables (Gulati \& Kumar, 2017). The study of (Yang \& Paradi, 2006) had referred this technique as 'handicap data envelopment analysis,' but there is no denying that there is a vast scope of application of this technique to a wide variety of data. An edifice of traditional DEA, known as window DEA, has been used in the current paper.

Most of the studies that have measured competency of DMUs with DEA are limited to the efficiency measurement of the DMUs for a single set of efficiency scores for a given time (Moghaddas \& Vaez-Ghasmi, 2016; Ramanathan, 2007; Yan et al., 2008; Yang \& Paradi, 2006). There are very few studies that have determined the efficiency trends using window analysis. Further, it has also been observed that the scope of the research for most of the literature in this discipline is limited to developed nations like the USA and European countries while neglecting the developing nations like India. The present study seeks to bridge this gap and focuses on the identification of the trend of efficiency scores among 18 Indian private banks for the period of 2005 to 2017.

\section{Research Data and Methodology}

\subsection{Data Envelopment Analysis}

The methods foster a piecewise-linear convex is the quant curve, which represents the best practicing DMUs located over the curve and other inefficient DMUs under it. The range of the score varies between 0 to 1 , which means one is for the most efficient unit, whereas a unit with a score of less than 1 is called an inefficient unit. By studying the distance relationship of the DMUs under the frontier with that of the efficient peer DMU, located on the frontier, one can quickly analyze the scope to enhance the output or limiting the inputs. In recent years, this method has gained the attention of many researchers and academicians, and thus there has been plenty of studies on the theoretical as well as practical applications of DEA(Bapat, 2012; Huguenin, 2013; Klimberg \& Ratick, 2008; Silva et al., 2018; Wanke \& Barros, 2014; Yeh, 1996). Further (Sufian, 2007) stated that one of the major rewards of using the DEA technique for measuring efficiency differentials is that the technique is independent of the sample sizes and can be equally utilitarian for research, which comprises of less data for analysis. There are several other advantages of this technique also. Firstly, All DMUs are identified by a unique score for efficiency, which makes it easier to benchmark and identify the most efficient DMU from the sample. Secondly, it underscores the key area of improvement for each DMU by comparing the relevant scores of DMU with the most efficient one, thus implying ways to develop the performance. Thirdly, to quantify the performance, using this technique is independent of any predefined functional form that is to be treated to the data in order to derive the efficiency scores. Finally, based on the efficiency scores, researchers can profile the DMU and its performance as compared to that of the DMU, which is lying on the efficient frontier. DEA is also flexible in the choice of input and output and does not require any kind of standardization of input and output units (Avkiran, 1999).

One of the most significant caveats attached to the approach of the data envelopment analysis is that the represented efficiency scores are not the actual determiner of efficiency as they are relative to the performance of the banks. It may be the case that any DMU not accounted for in the sample DMU could have better efficiency and better performance (Sathye, 2003).

\subsection{Analysis of Window Efficiency Scores}

The window analysis is a tool to study the variations in the efficiency scores of a DMU over a period. The technique of window analysis has been derived from a statistical method known as moving averages. This technique examines a DMU over different periods as separate units for analyzing the scores. It provides a comparison of similar DMU across different periods. Each DMU with multiple inputs and outputs across different years is considered as a distinct individual DMU. Thus, the application of data envelopment analysis associated with the time series data analysis is known as window analysis. A researcher can contrast the efficiency scores of banks across different periods through a sequence of windows that overlap each other for a given period. 
This technique assumes that there is no technical change for all DMUs during the period within each window. Thus, these results are better analyses of the performance of the DMU and a higher degree of freedom (Avkiran, 2004). The assumption of no technical change during the window period brings limitations that the tool cannot be applied for a large window. However, this limitation can be overcome by keeping the window size narrow. As such, there is no theoretical justification for the most appropriate size of the window period. For the current paper, the size of the window for using window analysis is three years. The breakdown of 11 windows is shown in Table 1. Thus, for the present study, the performance of 18 private sector banks is analyzed for 13 years using a window size of 3 years. A 3-year window of 18 private sector banks counts to a total of 54 separate DMUs. Subsequently, by applying

Table 1: Window breakdown for DEA window analysis on private sector banks for 2005-2017

\begin{tabular}{|l|c|c|c|}
\hline & Year 1 & Year 2 & Year 3 \\
\hline Window 1 & 2005 & 2006 & 2007 \\
\hline Window 2 & 2006 & 2007 & 2008 \\
\hline Window 3 & 2007 & 2008 & 2009 \\
\hline Window 4 & 2008 & 2009 & 2010 \\
\hline Window 5 & 2009 & 2010 & 2011 \\
\hline Window 6 & 2010 & 2011 & 2012 \\
\hline Window 7 & 2011 & 2012 & 2013 \\
\hline Window 8 & 2012 & 2013 & 2014 \\
\hline Window 9 & 2013 & 2014 & 2015 \\
\hline Window 10 & 2014 & 2015 & 2016 \\
\hline Window 11 & 2015 & 2016 & 2017 \\
\hline
\end{tabular}

this technique on 18 private sector banks for the period of 2005-2017 with 3 years taken together, the total number of observations increases to 594, which provides a better degree of freedom for the research.

The banking sector in India currently consists of 94,384 rural along with 1,562 urban cooperative banks. Further, the sector comprises 27 public, 21 private, 49 foreign, and 56 regional rural banks. This study focuses on a subset of 18 private sector banks that were operating in India from 2005 to 2017. The list of selected banks mentioned in Table 2 . In order to determine the efficiency scores using windows analysis, we have used EMS software version 1.3.

\subsection{Selection of Input and Outputs}

While there have been numerous researches and publications in the Indian banking sector, the choice and variety of input and output to study efficiency scores has been a disputed issue amongst researchers. The selection of the right type of input and output depends on the nature of the banking business. The literature in the area states that there are two broad approaches, which are used for capacity measurement of DMUs called production approach and intermediation approach. A hybrid of both production approach and the intermediary approach has also been suggested in the literature. Table 3 given below contrast various inputs and outputs that researchers generally used to study the effectiveness of the banks under the above mentioned two approaches.

The hybrid method, which is a mix of two approaches, as discussed above, extracts the merits of both approaches. The efficiency scores in our study have been calculated using this approach by using the following inputs and outputs (see Table 4).

The descriptive statistics for the various input and output variables used in the study given in Table 5 .

Table 2: The selected set of 18 private sector banks

\begin{tabular}{|l|l|c|l|}
\hline DMU Code & \multicolumn{1}{|c|}{ The Bank's Name } & DMU Code & \multicolumn{1}{c|}{ The Bank's Name } \\
\hline PR001 & Axis Bank & PR010 & Karnataka Bank Ltd \\
\hline PR002 & Catholic Syrian Bank Ltd & PR011 & Karur Vysya Bank Ltd \\
\hline PR003 & City Union Bank Limited & PR012 & Kotak Mahindra Bank Ltd. \\
\hline PR004 & DCB Bank Limited & PR013 & Lakshmi Vilas Bank Ltd \\
\hline PR005 & Federal Bank & PR014 & Nainital Bank Ltd \\
\hline PR006 & YES, Bank Ltd. & PR015 & RBL Bank Limited \\
\hline PR007 & ICICl Bank Limited & PR016 & South Indian Bank Ltd \\
\hline PR008 & IndusInd Bank Ltd & PR017 & Tamil Nadu Mercantile Bank \\
\hline PR009 & Jammu \& Kashmir Bank Ltd & PR018 & YES, Bank Ltd. \\
\hline
\end{tabular}


The descriptive statistics of the data indicates that interest income is a major part of their earnings. The average interest income is 4.76 times of non-interest income. Further, this ratio of interest income to non-interest income was maximum for Nainital bank in the year 2007, where interest income was 26.98 times more than non-interest income. Also, the descriptive statistics indicate that there is more considerable variability in the interest income over non-interest income. During the period of study, it has also been observed that in the year 2017, Yes bank is having the maximum number of employees, and also produces the maximum amount of loanable funds in comparison to its peers.

Table 3: Intermediate and production inputs and outputs

\begin{tabular}{|l|l|}
\hline \multicolumn{2}{|c|}{ Intermediate and Production Inputs and Outputs } \\
\hline Inputs & \multicolumn{1}{c|}{ Outputs } \\
\hline Number of Employees & Loans \\
\hline Fixed Assets & Deposits \\
\hline Capital & \\
\hline Inputs and Outputs used as per Intermediation Approach \\
\hline Inputs & Outputs \\
\hline Interest Expenses & Interest Income \\
\hline Non-Interest Expenses & Non-Interest Income \\
\hline
\end{tabular}

Table 4: Input and Outputs used in the study

\begin{tabular}{|l|l|}
\hline Input Variables & \multicolumn{1}{|c|}{ Output Variables } \\
\hline Fixed Assets (X1) & Interest Income (Y1) \\
\hline Number of employees (X2) & Non-interest Income (Y2) \\
\hline Loanable Fund (X3) & \\
\hline
\end{tabular}

\section{Empirical Results}

Using the software EMS 1.3 window analysis tool, the observation and scores for all 18 private sector banks for the period of 2005-2017, comprising of 11 windows of 3 years size, has brought insight on the trends of the efficiency amongst the Indian private sector banks. The mean efficiency scores of private sector banks across different windows are illustrated below in Table 6. It indicates that the mean efficiency score of PR018 - YES Bank Ltd. is showing a score of more than 1 across all 11 window periods. The mean efficiency score of the YES bank is 1.1064, which is higher than all other banks. It indicates that YES bank is the most efficient private sector bank across all window periods based on the mean efficiency score for all windows. Second to YES bank in terms of mean scores is PR007 - ICICI Bank Ltd. with a mean efficiency score of 1.032. Thus, the peer to peer comparison of the man efficiency scores indicates that ICICI bank can increase its revenue further by $6.44 \%$ to compete the benchmark scores set by YES Bank Ltd.

The efficiency scores indicate the appreciable performance of PR012 - Kotak Mahindra Bank and PR017- Tamil Nadu Mercantile Bank Ltd as both these banks are having an average efficiency score above 1 . The mean efficiency scores across all windows are found to be minimum at 0.748 in the case of PR015- RBL Bank Ltd. The mean efficiency score of RBL Bank Ltd indicates that there is a scope to increase the earnings of the bank further by $25.2 \%$ if inputs are optimized wisely. Further, it has also been observed that the efficiency score of most of the banks declined during the period of windows 3 and 4, which may be attributed to the global recession during that period. Overall for all private sector banks, the average efficiency score was found to be 0.8963 , which indicates that private sector banks in India operating between 2005 and 2017 are underutilizing their inputs and have a scope to further increase the outputs

Table 5: Descriptive Statistics of the Input and Outputs used in the study

\begin{tabular}{|l|c|c|c|c|c|}
\hline $\begin{array}{l}\text { Descriptive } \\
\text { Statistics }\end{array}$ & $\begin{array}{c}\text { Fixed Assets } \\
\{l\}\end{array}$ & $\begin{array}{c}\text { No. of employees } \\
\{l\}\end{array}$ & $\begin{array}{c}\text { Loanable Funds } \\
\{l\}\end{array}$ & $\begin{array}{c}\text { Interest Income } \\
\{\text { O\} }\end{array}$ & $\begin{array}{c}\text { Non-Interest Income } \\
\{\text { O\} }\end{array}$ \\
\hline Mean & 6990.27 & 11671.47 & 744848.75 & 68581.69 & 14399.75 \\
\hline Median & 2014.53 & 4624.50 & 241528.60 & 23395.92 & 2947.30 \\
\hline $\begin{array}{l}\text { Standard } \\
\text { Deviation }\end{array}$ & 12469.36647 & 17814.85673 & 1293086.663 & 118473.4504 & 29048.53441 \\
\hline Quartile 1 & 965.881 & 2652 & 94491.88425 & 8132.84225 & 1170.97375 \\
\hline Quartile 3 & 5303.497 & 9392.75 & 638799.7085 & 61770.68575 & 7817.95125 \\
\hline Min. & 56.41 & 207.00 & 7845.76 & 299.79 & 45.63 \\
\hline Max. & 78052.07 & 87555.00 & 7176685.23 & 693059.58 & 195044.83 \\
\hline Range & 77995.66 & 87348.00 & 7168839.47 & 692759.79 & 194999.20 \\
\hline
\end{tabular}


Table 6: Mean Efficiency scores of private sector banks across different windows

\begin{tabular}{|l|c|c|c|c|c|c|c|c|c|c|c|c|}
\hline & $\begin{array}{c}\text { WIN- } \\
\mathbf{0 1}\end{array}$ & $\begin{array}{c}\text { WIN- } \\
\mathbf{0 2}\end{array}$ & $\begin{array}{c}\text { WIN- } \\
\mathbf{0 3}\end{array}$ & $\begin{array}{c}\text { WIN- } \\
\mathbf{0 4}\end{array}$ & $\begin{array}{c}\text { WIN- } \\
\mathbf{0 5}\end{array}$ & $\begin{array}{c}\text { WIN- } \\
\mathbf{0 6}\end{array}$ & $\begin{array}{c}\text { WIN- } \\
\mathbf{0 7}\end{array}$ & $\begin{array}{c}\text { WIN- } \\
\mathbf{0 8}\end{array}$ & $\begin{array}{c}\text { WIN- } \\
\mathbf{0 9}\end{array}$ & $\begin{array}{c}\text { WIN- } \\
\mathbf{1 0}\end{array}$ & WIN- 11 & Avg. \\
\hline PR001 & 83.2 & 75.6 & 77.6 & 90.3 & 95.4 & 97.6 & 103.3 & 100.1 & 101.1 & 97.5 & 94.3 & 92.4 \\
\hline PR002 & 82.7 & 74.1 & 68.2 & 68.1 & 68.9 & 78.4 & 78.9 & 84.4 & 87.1 & 87.0 & 89.2 & 78.8 \\
\hline PR003 & 85.1 & 81.5 & 86.9 & 89.7 & 89.3 & 88.5 & 86.3 & 89.8 & 92.9 & 95.4 & 97.5 & 89.3 \\
\hline PR004 & 86.5 & 80.8 & 91.9 & 93.4 & 90.1 & 84.6 & 80.6 & 79.3 & 81.2 & 84.8 & 91.3 & 85.9 \\
\hline PR005 & 82.7 & 82.2 & 78.8 & 84.4 & 85.9 & 89.5 & 82.0 & 85.3 & 85.2 & 86.4 & 84.9 & 84.3 \\
\hline PR006 & 90.8 & 82.3 & 89.2 & 89.2 & 92.3 & 95.3 & 97.4 & 96.8 & 94.8 & 91.9 & 94.1 & 92.2 \\
\hline PR007 & 108.6 & 98.8 & 109.7 & 108.9 & 109.0 & 107.0 & 106.4 & 88.7 & 93.9 & 100.4 & 103.9 & 103.2 \\
\hline PR008 & 97.8 & 83.9 & 84.6 & 84.7 & 82.5 & 91.1 & 94.9 & 101.7 & 103.2 & 103.3 & 101.5 & 93.5 \\
\hline PR009 & 80.9 & 78.8 & 74.4 & 78.4 & 76.9 & 77.2 & 73.6 & 78.7 & 84.1 & 85.3 & 86.2 & 79.5 \\
\hline PR010 & 92.0 & 84.3 & 82.2 & 83.4 & 82.2 & 82.9 & 80.4 & 83.6 & 84.6 & 85.8 & 86.9 & 84.4 \\
\hline PR011 & 87.1 & 79.7 & 77.7 & 80.7 & 83.0 & 83.6 & 79.1 & 84.4 & 89.6 & 94.3 & 96.9 & 85.1 \\
\hline PR012 & 101.6 & 96.4 & 101.5 & 105.6 & 106.1 & 100.9 & 97.2 & 100.7 & 100.9 & 98.5 & 96.9 & 100.6 \\
\hline PR013 & 81.9 & 77.7 & 77.8 & 80.9 & 79.2 & 87.1 & 84.7 & 87.2 & 86.9 & 87.2 & 87.2 & 83.4 \\
\hline PR014 & 107.3 & 102.0 & 97.0 & 99.2 & 94.3 & 88.5 & 88.7 & 89.3 & 89.0 & 89.1 & 89.4 & 94.0 \\
\hline PR015 & 78.9 & 75.0 & 71.1 & 72.0 & 71.0 & 77.8 & 71.0 & 71.4 & 75.4 & 77.4 & 81.9 & 74.8 \\
\hline PR016 & 81.0 & 78.1 & 73.1 & 76.1 & 75.9 & 80.4 & 77.9 & 83.8 & 84.9 & 85.3 & 84.0 & 80.1 \\
\hline PR017 & 104.9 & 96.1 & 93.6 & 99.1 & 99.8 & 98.4 & 101.4 & 98.5 & 98.1 & 111.4 & 114.0 & 101.4 \\
\hline PR018 & 100.7 & 106.6 & 111.2 & 121.9 & 126.2 & 113.8 & 102.2 & 108.4 & 106.8 & 106.1 & 113.2 & 110.6 \\
\hline & & & & & & & & & & & & \\
\hline
\end{tabular}

by $10.37 \%$ with the given level of data. Also, the average overall efficiency score for 11 banks for all window period at $89.63 \%$ is also a healthy sign for the growth in sample private sector banks.

Table 7 depicts the frequency distribution for the efficiency scores of the banks in all 11 window periods for 18 banks. Therefore, the product of 11 window results of 18 banks represents 198 outcomes. DMUs having an efficiency score of 1 are termed as efficient, and those having an efficiency score of less than one are termed as under efficient. DMUs with an efficiency score of greater than 1 are called super practical. The above-given frequency distribution for the efficiency scores suggests that as much as $35.9 \%$ of all DMUs have operated at an efficiency score of more than 0.9 , which depicts an appreciable performance of private sector banks. There are only 3 occasions when DMUs scored between 0.6 to 0.7 , which is illustrated by PR002 (Catholic Syrian Bank Ltd.) from 2007 to 2009. It may be due to disturbances in the economic environment during that period. With $19.7 \%$ of banks operating at a super efficiency score of greater than one, it ensures growth prospects for the banks.Further, it can also be observed from the mean efficiency scores that out of 18 private sector banks, seven banks were having a score of greater than one. Out of these seven banks, YES bank Ltd. is found to be super-efficient for all the window periods, and this represents that YES Bank can be an ideal benchmark for all other private sector banks. All these banks have been evaluated as per suggested methods by which banks having high mean efficiency scores and relatively low standard deviation treated to be best in banking practices(Charnes \& Cooper, 1984).

It can be observed from Table 8 that PR010 (Karnataka Bank Ltd) is having a minimum standard deviation of 0.056 , which represents consistency in the efficiency scores for the bank. The maximum standard deviation is accounted for PR018 (Yes Bank Ltd), which is 0.174. It indicates a high risk of deviated expected efficiency score for Yes Bank Ltd. The positioning score of 0.063 for the first quartile results includes four banks (Karanataka, Lakshmi Vilas, Federal, and South Indian Bank). It can be observed from Table 8 that PR010 (Karnataka Bank Ltd) is having a minimum standard deviation of 0.056 , which represents consistency in the efficiency scores for the bank. The maximum standard deviation is accounted for PR018 (Yes Bank Ltd), which is 0.174 . It indicates a high risk of deviated expected efficiency score for Yes Bank Ltd. The positioning score of 0.063 for the first quartile results includes four banks (Karanataka, Lakshmi Vilas, Federal, and South Indian Bank). 
Table 7: Efficiency distribution of 18 private sector banks in 11 windows Efficiency values

\begin{tabular}{|l|c|c|c|}
\hline Efficiency Scores & Frequency & $\%$ & Cumulative Percentage \\
\hline Less than 0.6 & 0 & $0.00 \%$ & $0.00 \%$ \\
\hline Between 0.6 to 0.7 & 3 & $1.52 \%$ & $1.52 \%$ \\
\hline Between 0.7 to 0.8 & 35 & $17.68 \%$ & $19.19 \%$ \\
\hline Between 0.8 to 0.9 & 79 & $39.90 \%$ & $59.09 \%$ \\
\hline Between 0.9 to 1 & 42 & $21.21 \%$ & $80.30 \%$ \\
\hline 1 & 0 & $0.00 \%$ & $80.30 \%$ \\
\hline Greater than 1 & 39 & $19.70 \%$ & $100.00 \%$ \\
\hline
\end{tabular}

Table 8: Standard Deviation of the efficiency scores in 11 windows from 18 private sector banks

\begin{tabular}{|l|l|c|l|l|c|}
\hline Code & \multicolumn{1}{|c|}{ Name of the Bank } & $\boldsymbol{\sigma}$ & Code & \multicolumn{1}{c|}{ Name of The Bank } & $\boldsymbol{\sigma}$ \\
\hline PR001 & Axis Bank & 0.122 & PR010 & Karnataka Bank Ltd & 0.056 \\
\hline PR002 & Catholic Syrian Bank Ltd & 0.088 & PR011 & Karur Vysya Bank Ltd & 0.076 \\
\hline PR003 & City Union Bank Limited & 0.074 & PR012 & Kotak Mahindra Bank Ltd. & 0.102 \\
\hline PR004 & DCB Bank Limited & 0.100 & PR013 & Lakshmi Vilas Bank Ltd & 0.059 \\
\hline PR005 & Federal Bank & 0.060 & PR014 & Nainital Bank Ltd & 0.142 \\
\hline PR006 & Yes, Bank Ltd. & 0.065 & PR015 & RBL Bank Limited & 0.063 \\
\hline PR007 & ICICI Bank Limited & 0.151 & PR016 & South Indian Bank Ltd & 0.062 \\
\hline PR008 & IndusInd Bank Ltd & 0.101 & PR017 & Tamil Nadu Mercantile Bank Ltd & 0.106 \\
\hline PR009 & Jammu \& Kashmir Bank Ltd & 0.068 & PR018 & Yes, Bank Ltd. & 0.174 \\
\hline
\end{tabular}

Table 9: Efficiency Mapping Matrix for the efficiency scores of private banks in India

\begin{tabular}{|c|c|c|c|c|c|}
\hline \multirow{4}{*}{ 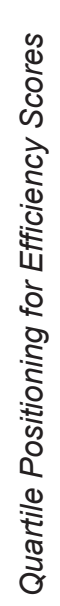 } & 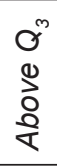 & & & Kotak Mahindra Bank & $\begin{array}{l}\text { Nanital Bank, } \\
\text { Tamil Nadu Mercantile Bank, } \\
\text { ICICI Bank } \\
\text { YES Bank }\end{array}$ \\
\hline & $\begin{array}{l}0^{\infty} \\
1 \\
0^{n}\end{array}$ & & City Union Bank & IndusInd Bank & Axis Bank \\
\hline & $\begin{array}{l}0^{2} \\
1 \\
0^{-}\end{array}$ & $\begin{array}{l}\text { Federal Bank } \\
\text { Karnataka Bank }\end{array}$ & Karur Vysya Bank & DCB Bank & \\
\hline & $\begin{array}{l}0 \\
3 \\
0 \\
0 \\
0 \\
0\end{array}$ & $\begin{array}{l}\text { South Indian Bank } \\
\text { Lakshmi Vilas Bank }\end{array}$ & $\begin{array}{l}\text { RBL Bank } \\
\text { Jammu \& Kashmir } \\
\text { Bank }\end{array}$ & Catholic Syrian Bank & \\
\hline & & Below $Q_{1}$ & $Q_{1}-Q_{2}$ & $Q_{2}-Q_{3}$ & Above $Q_{3}$ \\
\hline
\end{tabular}


Based on the position of banks' efficiency values and standard deviations of efficiency scores throughout the entire study period, a $4 \times 4$ matrix has been formed. The values of the standard deviation of efficiency scores are shown on the $\mathrm{x}$-axis, and the efficiency scores are shown on the y-axis. This matrix evaluates the consistency in the efficiency scores of the selective banks for the period of study. One can interpret that the bank with good efficiency scores, along with the least standard deviation scores, are the leaders or benchmarks for all other private sector banks. Thus, plotting the values of the selective banks on the matrix, it was observed there is no such bank that is producing a consistently high-efficiency score.

The matrix representation (Table 9) of the window analysis results for efficiency scores depicts that South Indian Bank and Lakshmi Vilas Bank are having the least efficiency values and are also consistent on the measure of standard deviation. Further, it is Nainital Bank, Tamil Nadu Mercantile Bank, ICICI Bank, and Yes banks that are having maximum efficiency scores. Still, the scores are not constant as per the values of standard deviation. It implies that the operations of such banks are risky, and despite being the most efficient banks, they must focus on bringing consistency to the efficiency scores.

\section{Conclusion}

The paper employs a window DEA to evaluate the efficiency of selective private sector banks from 2005 to 2017. Using the panel data and window analysis, the technique helps to identify the trends in efficiency scores of Indian private sector banks. The window analysis measures the trends in efficiency using the window period of 3 years. Thus, the time 2005 to 2017 is divided into 11 windows. The results depict that $59.9 \%$ of all private sector banks are currently operating at 0.9 efficiency score, which represents an appreciable performance of private sector banks. There are only three banks that are working with an efficiency score between 0.6 to 0.7 . Further analysis the consistency in the efficiency scores of the banks, the standard deviation of the man efficacy score of the bank in each window is analyzed, which indicate that PR010 (Karnataka Bank Ltd) is having the minimum standard deviation of 0.056, which represents consistency in the efficiency scores for the bank. The maximum standard deviation accounted for PR018 (Yes Bank Ltd), which is 0.174. It indicates a high risk of deviated expected efficiency score for Yes Bank Ltd.

The findings from the efficiency mapping matrix illustrate that South Indian Bank and Lakshmi Vilas Bank are having the lowest efficiency scores as well as standard deviation scores. It implies that these banks are operating at deficient efficiency scores along with little variability in the results. Further on the same level of the efficiency RBL Bank, Jammu and Kashmir Bank \& Catholic Syrian Banks are operating at higher standard deviation. These banks must take countermeasures to reduce variability in the results. Similarly, Federal Bank and Karnataka Bank were running on the same level of variability as of South Indian Bank and Lakshmi Vilas Bank, but are having more excellent efficiency position score. Thus, Federal Bank and Karanataka Bank must practice techniques for more excellent output maximization at the given level of input. On the central zone of the matrix, it observed that City Union Bank, IndusInd Bank, DCB Bank, Karur Vyasa Bank are having average efficiency scores and moderate variability. But even for these banks, there is a scope to maximize the efficiency and stable performance on efficiency scores.

As we move higher in the matrix, we can observe Nanital Bank, Tamil Nadu Mercantile Bank, ICICI Bank, and Yes bank is among the few banks that are showing the highest efficiency scores. Still, the efficiency results are highly variable also. There was no bank identified in the matrix that promises high-efficiency ratings with low variability. Thus, we conclude that the study of efficiency mapping matrix indicates that as a DMU move to a higher level of efficiency, the risk factor for the standard deviation also tends to rise. Considering the competence to be a key driver to the profitability of the firm, we can conclude that the findings of the study complement the concept of higher risk to higher return or greater efficiency. Such a matrix can help the banks in strategic planning and policy formations for their operations by analyzing their current position on the model and comparing it with the view of peers.

\section{Limitations and Future Directions}

We would like to acknowledge the following limitations of the study. Firstly, the scope of the present study is based on private sector banks and has not covered the public sector and foreign banks that are operating in the country. Secondly, the study is based on banks operating in India and has not contrasted with the efficiency scores for other developing nations. Thirdly, the period of the study is limited to 2005 to 2017. Thus, caution is required while interpreting and generalizing the results to the present year. Therefore, the study directs a scope of research to compare the efficiency scores of banks across a variety of ownership. Further, the results of the study can be applied to banks operating in other developing nations, and the results can thus provide a more comprehensive view of the concept and a better understanding of the idea. Empirical studies in the future can also expand the scope of the study to the current period. 


\section{References}

Abbas, J., Hussain, I., Hussain, S., Akram, S., Shaheen, I., \& Niu, B. (2019). The impact of knowledge sharing and innovation on sustainable performance in Islamic banks: A mediation analysis through a SEM approach. Sustainability, 11(15). https://doi. org/10.3390/su11154049

Ahmad, U. (2011). Financial reforms and banking efficiency: Case of Pakistan. MPRA Paper No. 34220. https://mpra.ub.unimuenchen.de/34220/

Akhigbe, A., McNulty, J. E., \& Stevenson, B. A. (2017). Does the form of ownership affect firm performance? Evidence from US bank profit efficiency before and during the financial crisis. Quarterly Review of Economics and Finance, 64, 120-129. https://doi.org/10.1016/j.qref.2016.07.015

Akhtar, M. H., \& Nishat, M. (2002). X-efficiency analysis of commercial banks in Pakistan: A preliminary investigation. The Pakistan Development Review, 41(4), 567-580. DOI: $10.2307 / 41263369$

Almumani, M. A. (2013). The Relative Efficiency of Saudi Banks: Data Envelopment Analysis Models. International Journal of Academic Research in Accounting, 3(3), 152-161. https://doi. org/10.6007/IJA

Anand, N., \& Kumar, A. (2020). Efficiency mapping of private banks in India through II-stage network DEA efficiency scores. International Journal of Scientific and Technology Research, 9(1), 3651-3657. Retrieved from www.ijstr.org

Arora, R. (2017). Marketing of banking services in India. In: Strategic Marketing Management and Tactics in the Service Industry (pp. 107-131). https://doi.org/10.4018/978-1-52252475-5.ch005

Asmild, M., Bogetoft, P., \& Leth Hougaard, J. (2013). Rationalising inefficiency: Staff utilisation in branches of a large Canadian bank. Omega, 41(1), 80-87. https://doi.org/10.1016/j. omega.2011.01.011

Asmild, M., Kronborg, D., Mahbub, T., \& Matthews, K. (2018). The efficiency patterns of Islamic banks during the global financial crisis: The case of Bangladesh. Quarterly Review of Economics and Finance, 74, 67-74. https://doi.org/10.1016/j. qref.2018.04.004

Avkiran. (2004). Decomposing Technical Efficiency and Window Analysis. Studies in Economics and Finance, 22, 61-91. https:// doi.org/10.1108/eb043383

Avkiran, N. K. (1999). The evidence on efficiency gains: The role of mergers and the benefits to the public. Journal of Banking and Finance, 23(7), 991-1013. https://doi.org/10.1016/S03784266(98)00129-0

Avkiran, N. K. (2015). An illustration of dynamic network DEA in commercial banking including robustness tests. Omega, 55, 141-150. https://doi.org/10.1016/j.omega.2014.07.002

Banna, H., Ahmad, R., \& Koh, E. H. Y. (2017). Determinants of Commercial Banks' Efficiency in Bangladesh: Does Crisis
Matter? Journal of Asian Finance, Economics and Business, 4(3), 19-26. https://doi.org/10.13106/jafeb.2017.vol4.no3.19

Banya, R., \& Biekpe, N. (2018). Banking efficiency and its determinants in selected frontier african markets. Economic Change and Restructuring, 51(1), 69-95. https://doi. org/10.1007/s10644-016-9200-3

Bapat, D. (2012). Vision-The Journal of Business Perspective, Indian Banker. Vinimaya, South Asian Journal of Management. and Advances in Management, 13. https://oi.org/10.1504/ IJBPM.2012.047299

Barros, C. P., Managi, S., \& Matousek, R. (2012). The technical efficiency of the Japanese banks: Non-radial directional performance measurement with undesirable output. Omega, 40(1), 1-8. https://doi.org/10.1016/j.omega.2011.02.005

Barros, C. P., \& Wanke, P. (2014). Banking efficiency in Brazil. Journal of International Financial Markets, Institutions and Money, 28(1), 54-65. https://doi.org/10.1016/j. intfin.2013.10.004

Baten, M. A., Kasim, M. M., \& Rahman, M. (2015). Efficiency and productivity change of selected online banks in Bangladesh: A non-parametric Malmquist approach. Journal of Internet Banking and Commerce. https://doi.org/10.4172/12045357.1000121

Bawa, J. K., Goyal, V., Mitra, S. K., \& Basu, S. (2019). An analysis of NPAs of Indian banks: Using a comprehensive framework of 31 financial ratios. IIMB Management Review. https://doi. org/10.1016/j.iimb.2018.08.004

Behera, D. S. K. (2019). Productivity Change of Indian Commercial Banks: A Non-Parametric Study. SSRN Electronic Journal. https://doi.org/10.2139/ssrn.3368797

Berger, A. N., \& Mester, L. J. (1997). Inside the black box: What explains differences in the efficiencies of financial institutions? Journal of Banking and Finance, 21(7), 895-947. https://doi. org/10.1016/S0378-4266(97)00010-1

Charnes, A., \& Cooper, W. W. (1984). Preface to topics in data envelopment analysis. Annals of Operations Research, 2(1), 59-94. https://doi.org/10.1007/BF01874733

Das, A., \& Kumbhakar, S. C. (2016). Markup and efficiency of Indian banks: an input distance function approach. Empirical Economics, 51(4), 1689-1719. https://doi.org/10.1007/s00181015-1062-4

Das, A., Nag, A., \& Ray, S. (2004). Liberalization, Ownership, and Efficiency in Indian Banking: A Nonparametric Approach. Economic and Political Weekly, 40(12), 1190-1197. DOI: $10.2307 / 4416367$

Doan, A. T., Lin, K. L., \& Doong, S. C. (2018). What drives bank efficiency? The interaction of bank income diversification and ownership. International Review of Economics and Finance, 55(C), 203-219. https://doi.org/10.1016/j.iref.2017.07.019

Eyceyurt Batir, T., Volkman, D. A., \& Gungor, B. (2017). Determinants of bank efficiency in Turkey: Participation banks 
versus conventional banks. Borsa Istanbul Review, 17(2), 8696. https://doi.org/10.1016/j.bir.2017.02.003

Forcadell, F. J., Aracil, E., \& Úbeda, F. (2019). The influence of innovation on corporate sustainability in the international banking industry. Sustainability, 11(11). https://doi. org/10.3390/su11113210

Gaganis, C., Liadaki, A., Doumpos, M., \& Zopounidis, C. (2009). Estimating and analyzing the efficiency and productivity of bank branches: Evidence from Greece. Managerial Finance, 35(2), 202-218. https://doi.org/10.1108/03074350910923518

Gemar, P., Gemar, G., \& Guzman-Parra, V. (2019). Modeling the sustainability of bank profitability using partial least squares. Sustainability, 11(18). https://doi.org/10.3390/su11184950

George, S. A. (2016). Productive efficiency, service quality and profitability: A comparative analysis of foreign and private banks in India. International Journal of Productivity and Quality Management, 18(4), 499-517. https://doi.org/10.1504/ IJPQM.2016.077780

Gulati, R., \& Kumar, S. (2017). Analysing banks' intermediation and operating efficiencies using the two-stage network DEA model: The case of India. International Journal of Productivity and Performance Management, 66(4), 500-516. https://doi. org/10.1108/IJPPM-03-2016-0055

Gunes, N., \& Yilmaz, A. (2016). Determinants of the Efficiencies in Turkish Banking Sector (Tobit Analysis). International Journal of Economics and Finance, 8(2), 215. https://doi.org/10.5539/ ijef.v8n2p215

Gupta, O. K., Doshit, Y., \& Chinubhai, A. (2008). Dynamics of productive efficiency of Indian banks. International Journal of Operations Research, 5(2), 78-90. Retrieved from www.iba. org.in

Hassan, M. (2019). How bank regulations impact efficiency and performance? Journal of Financial Economic Policy. https:// doi.org/10.1108/JFEP-06-2019-0119

Huguenin, J. M. (2013). Data Envelopment Analysis. In: MultiCriteria Decision Analysis: Methods and Software (pp. 235274). https://doi.org/10.1002/9781118644898.ch10

Ji, G., Kim, D. S., \& Ahn, K. (2019). Financial structure and systemic risk of banks: Evidence from Chinese reform. Sustainability, 11(13). https://doi.org/10.3390/su11133721

Klimberg, R. K., \& Ratick, S. J. (2008). Modeling data envelopment analysis (DEA) efficient location/allocation decisions. Computers and Operations Research, 35(2), 457-474. https:// doi.org/10.1016/j.cor.2006.03.010

Kumar, A. (2011). Analysis of Efficiency of Banks in a Developing Economy: A Case of India. International Journal of Computer Science and Management Studies, 11(03), 17-27.

Kumar, A., \& Dhingra, S. (2016a). Empirical Modeling of Profitability of Public Sector Banks in India. Prajnan, 45(2), 123-141.

Kumar, A., \& Dhingra, S. (2016b). Evaluating the efficiency of Indian public sector banks. International Journal of Indian
Culture and Business Management, 13(2), 226. https://doi. org/10.1504/ijicbm.2016.078041

Kumar, S. (2013). Banking reforms and the evolution of cost efficiency in Indian public sector banks. Economic Change and Restructuring, 46(2), 143-182. https://doi.org/10.1007/ s10644-012-9121-8

Kumar, S., \& Gulati, R. (2009). Did efficiency of Indian public sector banks converge with banking reforms? International Review of Economics, 56(1), 47-84. https://doi.org/10.1007/ s12232-008-0057-2

Le, T. T. D. (2020). Determinants of Retail Banking Efficiency: A Case of Vietcombank Branches in the Mekong-Delta Region. Journal of Asian Finance, Economics and Business, 7(7), 439-451. https://doi.org/10.13106/jafeb.2020.vol7.no7.439

Lovell, K., Bhattacharyya, A., Lovell, C. A. K., \& Sahay, P. (1997). The Impact of Liberalization on the Productive Efficiency of Indian Commercial Banks, European Journal of Operational Research, 98, 332-345. https://doi.org/10.1016/S0377-2217(96)00351-7

Ma, L., Zhai, Y., \& Wu, T. (2019). Operating charging infrastructure in China to achieve sustainable transportation: The choice between company-owned and franchised structures. Sustainability, 11(6). https://doi.org/10.3390/su11061549

Mahathanaseth, I., \& Tauer, L. W. (2014). Performance of Thailand banks after the 1997 East Asian financial crisis. Applied Economics, 46(30), 3763-3776. https://doi.org/10.1080/00036 846.2014.937036

Martín, J. C., \& Román, C. (2001). An application of DEA to measure the efficieny of Spanish airports prior to privatization. Journal of Air Transport Management, 7(3), 149-157. https:// doi.org/10.1016/S0969-6997(00)00044-2

Miencha, I. O., \& Selvam, M. (2013). Operational Efficiency and Profitability of Kenyan Commercial Banks. SSRN Electronic Journal. https://doi.org/10.2139/ssrn.2335851

Moghaddas, Z., \& Vaez-Ghasmi, M. (2016). Ranking models in data envelopment analysis technique. Data Envelopment Analysis and Effective Performance Assessment, 6(4), 265-311. https://doi.org/10.4018/978-1-5225-0596-9.ch007

Mukherjee, A., Nath, P., \& Pal, M. (2003). Resource, service quality and performance triad: A framework for measuring efficiency of banking services. Journal of the Operational Research Society, 54(7), 723-735. https://doi.org/10.1057/palgrave.jors.2601573

Mukherjee, Avinandan, Nath, P., \& Pal, M. (2002). Performance benchmarking and strategic homogeneity of Indian banks. International Journal of Bank Marketing, 20(3), 122-139. https://doi.org/10.1108/02652320210430965

Mutiga, S. K., Mushongi, A. A., \& Kangéthe, E. K. (2019). Enhancing food safety through adoption of long-term technical advisory, financial, and storage support services in maize growing areas of East Africa. Sustainability, 11(10). https://doi. org/10.3390/su11102827

Nandi, J. K. (2013). Efficiency Analysis of Selected Public and Private Sector Banks in India Through Data. Vidyasagar University Journal of Commerce, 18, http://inet.vidyasagar. 
ac.in:8080/jspui/bitstream/123456789/1017/2/J.K.\%20Nandi. pdf

Naushad, M., Faridi, M. R., \& Faisal, S. (2020). Measuring the Managerial Efficiency of Insurance Companies in Saudi Arabia: A Data Envelopment Analysis Approach. Journal of Asian Finance, Economics and Business, 7(6), 297-304. https:// doi.org/10.13106/jafeb.2020.vol7.no6.297

Nguyen, O. T. (2020). Factors Affecting the Intention to Use Digital Banking in Vietnam. Journal of Asian Finance, Economics and Business, 7(3), 303-310. https://doi.org/10.13106/jafeb.2020. vol7.no3.303

Padake, V., \& Soni, R. (2015). Measurement of Efficiency Through Dupont Analysis: A Study of Top 12 Banks in India. The IUP Journal of Bank Management, 14(November), 1-11.

Paradi, J. C., Sherman, H. D., \& Tam, F. K. (2018). Bank branch productivity applications: Managing bank productivity. In: International Series in Operations Research and Management Science (Vol. 266, pp. 101-112). https://doi.org/10.1007/978-3319-69725-3_7

Pham Thien, T., Hong, S., Pham Thien Nguyen, T., \& Hong Nghiem, S. (2015). The Interrelationships among Default Risk, Capital Ratio and Efficiency: Evidence from Indian Banks. https://doi. org/10.1108/MF-12-2013-0354

R., S. (2013). A Study on Technical Efficiency of Public Sector Banks in India. International Journal of Business and Economics Research, 2(2), 15. https://doi.org/10.11648/j. ijber.20130202.11

Ramanathan, R. (2007). Performance of banks in countries of the gulf cooperation council. International Journal of Productivity and Performance Management, 56(2), 137-154. https://doi. org/10.1108/17410400710722635

Saad, W., \& El-Moussawi, C. (2009). Evaluating the Productive Efficiency of Lebanese Commercial Banks: Parametric and Non-Parametric Approaches. International Management Review, 5(1), 5-19.

Saha, A., \& Ravisankar, T. S. (2000). Rating of Indian commercial banks: a DEA approach. European Journal of Operational Research, 124(1), 187-203. https://doi.org/10.1016/S03772217(99)00167-8

Sathye, M. (2003). Efficiency of banks in a developing economy: The case of India. European Journal of Operational Research, 148(3), 662-671. https://doi.org/10.1016/S03772217(02)00471-X

Sathye, M. (2005). Privatization, performance, and efficiency: A study of indian banks. Vikalpa, 30(1), 7-16. https://doi. org/10.1177/0256090920050102

Sathye, M., \& Khankhoje, D. (2009). Compliance and Effectiveness Analysis of the Mutual Evaluation Reports of Financial Action Task Force Member Countries View project Efficiency of Rural Banks: The Case of India. https://doi.org/10.5539/ibr.v1n2p140
Seelanatha, L. (2010). Market structure, efficiency and performance of banking industry in Sri Lanka. Banks and Bank Systems, 5(1), 20-31.

Sensarma, R. (2008). Deregulation, ownership and profit performance of banks: Evidence from India. Applied Financial Economics, 18(19), 1581-1595. https://doi. org/10.1080/09603100701720385

Silva, T. C., Tabak, B. M., Cajueiro, D. O., \& Dias, M. V. B. (2018). Adequacy of deterministic and parametric frontiers to analyze the efficiency of Indian commercial banks. Physica A: Statistical Mechanics and Its Applications, 506, 1016-1025. https://doi.org/10.1016/j.physa.2018.04.100

Singh, P. K., \& Thaker, K. (2016). Dynamics of scale effficiency of Indian banks: A deterministic frontier approach. The Journal of Developing Areas. https://doi.org/10.1353/jda.2016.0113

Sufian, F. (2007). Trends in the efficiency of Singapore's commercial banking groups: A non-stochastic frontier DEA window analysis approach. In International Journal of Productivity and Performance Management (Vol. 56). https:// doi.org/10.1108/17410400710722626

Sufian, F., \& Shah Habibullah, M. (2010). Developments in the efficiency of the Thailand banking sector: a DEA approach. International Journal of Development Issues, 9(3), 226-245. https://doi.org/10.1108/14468951011073316

Tahir, M., Shah, S. S. A., \& Afridi, M. A. (2016). Assessing nature of competition in banking sector of Pakistan. The Journal of Finance and Data Science, 2(4), 244-253. https://doi. org/10.1016/j.jfds.2017.04.001

Tecles, P. L., \& Tabak, B. M. (2010). Determinants of bank efficiency: The case of Brazil. European Journal of Operational Research, 207(3), 1587-1598. https://doi.org/10.1016/j.ejor.2010.06.007

Wanke, P., Azad, M. D. A. K., \& Barros, C. P. (2016). Predicting efficiency in Malaysian Islamic banks: A two-stage TOPSIS and neural networks approach. Research in International Business and Finance, 36, 485-498. https://doi.org/10.1016/j. ribaf.2015.10.002

Wanke, P., \& Barros, C. (2014). Two-stage DEA: An application to major Brazilian banks. Expert Systems with Applications, 41(5), 2337-2344. https://doi.org/10.1016/j.eswa.2013.09.031

Wijesiri, M., Viganò, L., \& Meoli, M. (2015). Efficiency of microfinance institutions in Sri Lanka: A two-stage double bootstrap DEA approach. Economic Modelling, 47, 74-83. https://doi.org/10.1016/j.econmod.2015.02.016

Yan, J., Zhang, T., Wu, Z., \& Liu, H. (2008). Data envelopment analysis and its application in supplier selection. In: Proceedings of the 8th International Conference of Chinese Logistics and Transportation Professionals - Logistics: The Emerging Frontiers of Transportation and Development in China. https:// doi.org/10.1061/40996(330)216

Yang, Z., \& Paradi, J. C. (2006). Cross firm bank branch benchmarking using "handicapped" Data Envelopment Analysis to adjust for corporate strategic effects. Proceedings 
of the Annual Hawaii International Conference on System Sciences, 2. https://doi.org/10.1109/HICSS.2006.104

Yeh, Q. J. (1996). The application of data envelopment analysis in conjunction with financial ratios for bank performance evaluation. Journal of the Operational Research Society, 47(8), 980-988. https://doi.org/10.1057/jors.1996.125
Zhou, G., Min, H., xu, C., \& Cao, Z. (2008). Evaluating the comparative efficiency of Chinese third-party logistics providers using data envelopment analysis. International Journal of Physical Distribution \& Logistics Management, 38(4), 262-279. https://doi.org/10.1108/09600030810875373 